\title{
PENERAPAN MODEL COOPERATIVE LEARNING TIPE TEAM ASSISTED INDIVIDUALIZATION (TAI) UNTUK MENINGKATKAN KEMAMPUAN PENALARAN DAN KOMUNIKASI MATEMATIS SERTA MENGEMBANGKAN SELF-EFFICACY PESERTA DIDIK SMA
}

\author{
Melinda Putri Mubarika \\ Universitas Pasundan \\ melinda.p.mubarika@unpas.ac.id
}

\begin{abstract}
ABSTRAK
Pendekatan penelitian yang digunakan adalah mixed methods dengan convergen design. Instrumen yang digunakan berupa soal tes kemampuan penalaran dan komunikasi, angket self efficacy, lembar observasi guru dan peserta didik, juga wawancara. Berdasarkan hasil penelitian yang telah dilaksanakan dari sebanyak Sembilan kali pertemuan menunjukkan bahwa : 1) penerapan model cooperative learning tipe Time Assisted Individualization (TAI) dapat meningkatkan kemampuan penalaran peserta didik; 2) penerapan model cooperative learning tipe Time Assisted Individualization (TAI) dapat meningkatkan kemampuan komunikasi peserta didik; 3) kemampuan penalaran dan komunikasi matematis selama pembelajaran berlangsung dapat diatasi dengan baik, dan ada peningkatan pada setiap pertemuan; 4) perkembangan self-eficacy peserta didik selama proses pembelajaran matematika dengan penerapan model cooperative learning tipe Time Assisted Individualization (TAI) berada pada kategori sedang, baik secara keseluruhan maupun berdasarkan dimensi magnitude, strength, dan generality; 5) terdapat hubungan yang positif antara kemampuan penalaran dan kemampuan komunikasi matematis dengan self efficacy peserta didik; 6) kendala yang dihadapi peserta didik dalam menyelesaikan tes kemampuan penalaran dan komunikasi matematis bisa diatasi dalam batas pencapaian kriteria ketuntasan minimal yang sudah ditetapkan pada awal penelitian dan didakan evaluasi dalam setiap pertemuannya.
\end{abstract}

Kata kunci: Komunikasi, Penalaran, Cooperative Learning, Team Assisted Individualization (TAI), Self-Efficacy

\begin{abstract}
The research approach used is mixed methods with convergent design. The instruments used were tests of reasoning and communication skills, self efficacy questionnaires, teacher and student observation sheets, as well as interviews. Based on the results of research that has been carried out from as many as nine meetings showed that: 1) the application of the cooperative learning model Time Assisted Individualization (TAI) type can improve students' reasoning abilities; 2) the application of the cooperative learning model Time Assisted Individualization (TAI) type can improve students' communication skills; 3) mathematical reasoning and communication skills during the learning process can be overcome properly, and there is an increase in each meeting; 4) the development of students' self-efficacy during the mathematics learning process by applying the cooperative learning model Time Assisted Individualization (TAI) type is in the medium category, both overall and based on the dimensions of magnitude, strength, and generality; 5) there is a positive relationship between reasoning abilities and mathematical communication skills with students' self efficacy; 6 ) the obstacles faced by students in completing mathematical reasoning and communication skills tests can be overcome within the limits of achieving the minimum completeness criteria that have been set at the beginning of the study and are evaluated in each meeting.
\end{abstract}

Keywords: Communication, reasoning, Cooperative Learning, Team Assisted Individualization (TAI), and Self-Efficacy 


\section{PENDAHULUAN}

Suatu kondisi saat ini dalam proses pembelajaran matematika, peserta didik memperlihatkan kurangnya ketertarikan dan keingintahuan dalam mempelajari matematika. Hal ini dikarenakan masih banyak ditemukan permasalahan yang kompleks. Permasalahan tersebut dikarenakan peserta didik terbiasa menyelesaikan permasalahan matematika secara prosedural tanpa memahami konsep, sehingga tidak terjadi proses pemaknaan dan pemahaman matematika, jadi wajar saja jika pelajaran matematika menjadi tidak menyenangkan dan sehingga sangat sulit untuk dipahami.

Untuk menciptakan pembelajaran yang menyenangkan dan mudah dipahami, seorang guru haruslah mampu membangun euphoria peserta didik supaya tercipta pembelajaran yang dinamis dan efektif. Salah satunya dengan menerapkan model-model pembelajaran, selain itu guru juga harus membangun suasana agar peserta didik dapat saling bekerjasama.

Dalam proses pembelajaran matematika yang perlu ditingkatkan adalah kemampuan matematis diantaranya kemampuan penalaran dan komunikasi matematis. Kemampuan penalaran dan komunikasi matematis berperan penting dalam keberhasilan peserta didik. Kenyataannya untuk peserta didik sekolah menengah, kemampuan penalaran dan komunikasi yang dimiliki peserta didik masih kurang memuaskan.

Kemampuan penalaran matematis merupakan proses berpikir untuk menghubungkan fakta-fakta yang dalam masalah matematika, yang kemudian menghasilkan suatu kesimpulan. Jika peserta didik telah memahami akan fakta-fakta tersebut, maka pengetahuan yang dimiliki peserta didik terhadap suatu materi akan lebih lama berada di dalam pikiran mereka, dan dapat diaplikasikan dalam berbagai situasi, sehingga kemampuan yang mereka miliki tidak hanya melakukan apa yang diperintahkan saja, tetapi mereka berusaha mencari pemahaman sendiri tidak mengikuti langkah-langkah logis saja.. Dari keterangan tersebut, dapat disimpulkan bahwa untuk meningkatkan kemampuan penalaran peserta didik diperlukan suatu pengembangan materi pelajaran matematika yang difokuskan pada kesadaran tentang pengetahuan dan proses berpikir peserta didik. Mereka harus memiliki kesadaran bahwa mereka perlu tahu konsep-konsep yang melandasi untuk memecahkan masalah.

Kemampuan komunikasi merupakan komponen yang penting dalam proses pembelajaran matematika. Penelitian yang dilakukan Huang \& Normandia (2009) mengungkapkan bahwa refleksi dan komunikasi adalah proses kunci dalam membangun pemahaman. Sejalan dengan itu Kosko, Wilkins \& Jesse (2010) menyatakan bahwa 
kemampuan komunikasi matematis akan membantu peserta didik untuk mengekspresikan pemikirannya dalam menjelaskan strategi, meningkatkan pengetahuan mereka dalam menulis algoritma, dan umumnya untuk meningkatkan kemampuan kognitif.

Berdasarkan hasil diskusi dengan teman sejawat pada hari Kamis, tanggal 19 Juli 2017 bahwa masih rendahnya kemampuan peserta didik dalam pembelajaran matematika hal ini disebabkan dikarenakan input dan output peserta didik yang beragam. Kemampuan pemahaman konsep dasar dan prosedur matematika masih sangat rendah sehingga untuk menyelesaikan setiap materi masih harus diulang-ulang. Dengan adanya tuntutan kurikulum nasional edisi revisi 2017 terlalu berat untuk dilaksanakan, karena peserta didik belum terbiasa bernalar logis dalam menganalisis permasalahan untuk menemukan konsep, bahkan untuk mengomunikasikan hasil kerja sangatlah rendah, karena tingkat keyakinan pribadinya tergolong rendah, sehingga membuat proses pembelajaran terhambat oleh faktor-faktor tersebut.

Berdasarkan latar belakang yang sudah dijelaskan di atas, peneliti melakukan penerapan model pembelajaran untuk meningkatkan kemampuan penalaran dan komunikasi serta mengembangkan self efficacy. Adapun model yang digunakan yaitu cooperative learning tipe Team Assisted Individualization (TAI) dalam pembelajaran Matematika. Karena pembelajaran yang mengacu pada model cooperative learning tipe Team Assisted Individualization (TAI) lebih memfokuskan pada kesuksesan peserta didik dalam mengorganisasikan pengalaman mereka, dengan kata lain peserta didik akan mendapatkan pengalaman untuk mengkonstruksikan sendiri pengetahuan mereka melalui asimilasi dan akomodasi bersama kelompoknya. Pengetahuan itu tidak dapat dipindahkan secara utuh dari pikiran guru ke peserta didik, namun secara aktif dibangun oleh peserta didik sendiri melalui pengalaman nyata, hal ini sesuai dengan apa yang dilakukan oleh Piaget, yaitu belajar merupakan proses adaptasi terhadap lingkungan yang melibatkan asimilasi, yaitu proses bergabungnya stimulus kedalam struktur kognitif. Bila stimulus baru tersebut masuk kedalam struktur kognitif diasimilasikan, maka akan terjadi proses adaptasi yang disebut kesinambungan dan struktur kognitif menjadi bertambah.

\section{Model Cooperative Learning tipe Team Assisted Individualization (TAI)}

Model cooperative learning tipe team assisted individualization (TAI) merupakan pembelajaran yang berpusat pada peserta didik (student centered). Dalam pelaksanaan pembelajaran biasanya peserta didik diberikan lembar aktivitas peserta didik (LAPD) secara berkelompok, kemudian mereka berdiskusi untuk menemukan atau memahami konsep. Setiap anggota kelompok dapat mengerjakan soal sebagai bentuk tanggungjawab 
bersama. Penerapan model cooperative learning tipe team assisted individualization (TAI) lebih menekankan pada penghargaan kelompok, pertanggungjawaban individu dan memperoleh kesempatan yang sama untuk berbagi hasil bagi setiap anggota kelompok

Robert Slavin (1995) (dalam Ibrahim, 2000) mengembangkan model cooperative learning tipe team assisted individualization (TAI) ini dengan beberapa alasan, yaitu : (1) model ini mengkombinasikan keunggulan kooperatif dan program pengajaran individual; (2) model ini memberikan tekanan pada efek sosial dari belajar kooperatif; (3) model ini disusun untuk memecahkan masalah dalam program pengajaran [misalnya, hal kesulitan belajar peserta didik secara individual].

Tabel 1. Sintaks Pelaksanaan Team Assisted Individualization (TAI)

\begin{tabular}{|c|c|c|}
\hline Langkah & Indikator & Tingkah Laku Guru \\
\hline Langkah 1 & Placement Test & $\begin{array}{l}\text { Guru memberikan tes awal (pretes) kepada } \\
\text { peserta didik. Bisa digantikan dengan } \\
\text { mencermati rata-rata nilai harian atau nilai } \\
\text { pada bab sebelumnya yang diperoleh peserta } \\
\text { didik sehingga guru dapat mengetahui } \\
\text { kekurangan dan kelebihan peserta didik }\end{array}$ \\
\hline Langkah 2 & Teams & $\begin{array}{l}\text { kelompok yang bersifat heterogen terdiri } \\
\text { dari } 4 \text { - } 5 \text { orang peserta didik. Kemudian } \\
\text { guru melakukan teaching group (guru } \\
\text { memberikan materi secara singkat } \\
\text { menjelang pemberian tugas kelompok). }\end{array}$ \\
\hline Langkah 3 & Student Creative & $\begin{array}{l}\text { Guru menekankan dan menciptakan persepsi } \\
\text { bahwa keberhasilan setiap peserta didik } \\
\text { ditentukan oleh keberhasilan kelompoknya. }\end{array}$ \\
\hline Langkah 4 & Team Study & $\begin{array}{l}\text { Peserta didik belajar bersama dengan } \\
\text { mengerjakan tugas-tugas dari LAPD yang } \\
\text { diberikan dalam kelompoknya. Pada } \\
\text { tahapan ini guru memberikan bantuan secara } \\
\text { individual kepada peserta didik yang } \\
\text { membutuhkan, dengan dibantu peserta didik } \\
\text { yang memiliki kemampuan akademis bagus } \\
\text { di dalam kelompok (tutor sebaya). }\end{array}$ \\
\hline Langkah 5 & Fact Test & $\begin{array}{l}\text { Guru memberikan tes-tes kecil berdasarkan } \\
\text { fakta yang diperoleh peserta didik dengan } \\
\text { memberikan kuis. }\end{array}$ \\
\hline
\end{tabular}




\begin{tabular}{ccc}
\hline Langkah & \multicolumn{1}{c}{ Indikator } & \multicolumn{1}{c}{ Tingkah Laku Guru } \\
\hline Langkah 6 & Team Score dan Team & Guru memberikan skor pada hasil kerja \\
& Recognition & kelompok dan memberikan penghargaan \\
Langkah 7 & Whole-Class Units & terhadap kelompok yang berhasil . \\
& & Guru menyajikan kembali materi diakhir \\
& & bab dengan strategi pemecaham masalah \\
& & untuk seluruh peserta didik di kelasnya.
\end{tabular}

Sumber : (Slavin, Robert : 1995, dalam Wahyudi; 2013)

\section{Kemampuan Penalaran Matematis}

Menurut Sumarmo (dalam Pakpahan, 2014) secara garis besar mengungkapkan bahwa penalaran digolongkan ke dalam dua jenis yaitu penalaran induktif dan penelaran deduktif. Penalaran induktif merupakan penarikan kesimpulan dari umum atau khusus berdasarkan data yang diamati. Nilai kebenaran dalam penalaran induktif dapat bersifat benar atau salah.

Adapun kegiatan yang tergolong ke dalam penalaran induktif adalah : (a) transduktif; (b) analogi; (c) generalisasi; (d) memperkirakan jawaban, solusi atau kecenderungan (e) memberi penjelasan terhadap model, fakta, sifat, hubungan atau pola (f) menggunakan pola hubungan untuk menganalis situasi, dan menyusun konjektur.

Penalaran deduktif merupakan penarikan kesimpulan berdasarkan aturan yang disepakati. Nilai kebenarann dalam penalaran bersifat mutlak benar atau salah atau tidak keduanya. Sedangkan menurut Keraf (Shadiq, 2004), penalaran adalah suatu proses atau suatu aktivitas berpikir untuk menarik suatu kesimpulan atau proses berpikir dalam rangka membuat suatu pernyataan baru yang benar berdasarkan pada beberapa pernyataan kebenarannya telah dibuktikan atau diasumsikan sebelumnya. Materi yang terkait dalam pembelajaran matematika dipahami melalui penalaran, dan penalaran dipahami dan dilatihkan melalui pembelajaran.

Untuk mengukur kemampuan penalaran peserta didik diperlukan adanya indikator sebagai tanda dalam pengukuran. Adapun indikator kemampuan penalaran peserta didik menurut peraturan Dirjen Dikdasmen Depdiknas Nomor 506/C/Kep/PP/2004 (dalam Nita, 2014) yaitu peserta didik mampu : (a) mengajukan dugaan; (b) melakukan manipulasi matematika; (c) menyusun bukti, memberikan alasan atau bukti terhadap kebenaran solusi; (d) menarik kesimpulan dari pernyataan; (e) memeriksa kesahihan dari pernyataan; (f) menemukan pola atau sifat dari gejala matematis untuk membuat generalisasi. 


\section{Kemampuan Komunikasi Matematis}

Dalam komunikasi matematika, peserta didik dilibatkan secara aktif untuk berbagi ide dengan peserta didik lain dalam mengerjakan soal-soal matematika. Komunikasi matematika merupakan cara untuk menyelesaikan permasalahan matematika yang memerlukan sebuah kemasan yang komplit, karena selain merepresentasikan di dalam pemikiran sendiri, harus juga menuangkan ide secara tertulis atau lisan. Peserta didik mempelajari matematika dengan apa yang mereka pikirkan, apa yang mereka tulis, dan langkah-langkah matematika yang sedang dikerjakan. Peserta didik terlibat secara aktif dalam mengerjakan matematika, ketika apa yang diperintahkan dalam mengerjakan permasalahan matematika harus terlibat secara keseluruhan, menuangkan ide, gagasan, menemukan, kemudian menuangkan semua dalam bentuk tertulis maupun lisan.

Tujuan mengembangkan kemampuan komunikasi matematis dalam pembelajaran dikemukakan NCTM (2000) (dalam Sumarmo, 2017 : 60) yaitu : (1) mengorganisasikan dan menggabungkan cara berpikir matematik, mendorong belajar konsep baru dengan cara menggambar objek, menggunakan diagram, menulis, dan menggunakan symbol matematis; (2) mengomunikasikan pemikiran matematika secara logis dan jelas sehingga mudah dimengerti; (3) menganalisis dan mengevaluasi pemikiran matematik dan strategi lain, bereksplorasi mencari cara dan strategi lain dalam menyelesaikan masalah; (4) menggunakan bahasa matematik untuk mengekspresikan ide-ide dengan benar.

Berikut adalah indicator kemampuan komunikasi matematis seseorang menurut Sumarmo (dalam Zanthy, 2011) yaitu: (1) menyatakan suatu situasi, gambar, diagram, atau benda nyata ke dalam bahasa, simbol, ide, atau model matematika; (2) menjelaskan ide, situasi, dan relasi matematika secara lisan atau tulisan; (3) mendengarkan, berdiskusi, dan menulis tentang matematika; (4) membaca dengan pemahaman suatu representasi matematika tertulis; (5) membuat konjektur, merumuskan definisi, dan generalisasi; (6) mengungkapkan kembali.

\section{Self Efficacy}

Self-efficacy menurut Bandura (dalam Sumarmo, 2017:212) yakni keyakinan individu mengenai kemampuan dirinya dalam melakukan tugas atau tindakan yang diperlukan untuk mencapai hasil tertentu. Self-efficacy mengacu pada keyakinan akan kemampuan individu untuk menggerakkan motivasi, kemampuan kognitif, dan tindakan yang diperlukan untuk memenuhi tuntutan situasi. Self-efficacy merupakan keyakinan seseorang terhadap apa yang mampu dilakukan terhadap sesuatu yang dituju. Self-efficacy 
difokuskan pada keomponen-komponen keyakinan diri yang dimiliki seseorang dalam menghadapi situasi yang dihadapi.

Menurut Bandura (dalam Sumarmo, 2017: 211) Persepsi Self-efficacy dibentuk dengan menginterpretasikan informasi dari empat sumber yaitu: (1) Pengalaman otentik: merupakan pengalaman pribadi yang dialami oleh sesorang, dan merupakan sumber yang berpengaruh terhadap tingkat keyakinan seseorang, karena tingkat kegagalan dan tingkat keberhasilan pengalaman yang sudah berlalu dapat menurunkan atau meningkatkan Selfefficacy seseorang; (2) Pengalaman orang lain: pengalaman yang diperlukan seseorang untuk menegaskan sebuah keputusan akan kemampuan pribadinya, dan ini merupakan sumber yang diperlukan dalam self efficacy seseorang; (3) Pendekatan sosial atau verbal: pendekatan seseorang terhadap individu lain untuk meyakinkan bahwa individu tersebut memiliki kemampuan untuk melakukan sesuatu; (4) Indeks psikologis: kondisi seseorang berdasarkan emosi yang akan mempengaruhinya, dan diberi penilaian kemampuan oleh ahlinya.

Self-efficacy seseorang terdapat dalam berbagai dimensi dan sangat terintegrasi dengan apa yang dilakukan oleh seseorang dalam menghadapi sesuatu hal.. Menurut Bandura (1997) (dalam Nita, 2014) menyatakan bahwa pengukuran self efficacy yang dimiliki seseorang mengacu pada tiga dimensi yaitu magnitude, strength dan generality. Setiap dimensi ini memberi implikasi penting bagi performen seseorang.

1. Dimensi magnitude/level berhubungan dengan tingkat kesulitan yang diyakini oleh individu untuk dapat diselesaikan. Misalnya jika seseorang dihadapkan pada masalah atau tugas-tugas yang disusun menurut tingkat kesulitan tertentu, maka self-efficacy individu akan jatuh pada tugas-tugas yang mudah, sedang, dan sulit sesuai dengan batas kemampuan yang dirasakan untuk memenuhi tuntutan perilaku yang dibutuhkan bagi masing-masing tingkatnya tersebut.

2. Dimensi strength berhubungan dengan tingkat kekuatan atau kelemahan keyakinan individu tentang kompetensi yang dipersepsinya. Dengan kata lain, dimensi ini menunjukkan derajat kemantapan seseorang terhadap keyakinannya tentang kesulitan tugas yang biasa dikerjakan. Dimensi ini biasanya berkaitan langsung dengan dimensi magnitude/level, yakni makin tinggi taraf kesulitan tugas, maka makin lemah keyakinan yang dirasakanuntuk menyelesaikannya. Seseorang dengan self efficacy yang lemah mudah dikalahkan oleh pengalaman yang sulit. Sedangkan orang yang memiliki self efficacy yang kuat dalam kompetensi akan mempertahankan usahanya walaupun mengalami kesulitan. 
3. Dimensi generality menunjukkan apakah self efficacy akan berlangsung dalam domain tertentu atau berlaku dalam berbagai macam aktivitasdan situasi. Dimensi ini berhubungan dengan luas bidang atau tingkat pencapaian keberhasilan seseorang dalam mengatasi atau menyelesaikan masalah atau tugas-tuganya. Selain itu mengacu pada keleluasaan dari Self-efficacy yang dimiliki seseorang yang dapat diterapkan dalam situasi lain.

\section{METODE}

Penelitian menggunakan metode penelitian mix methods, yaitu suatu prosedur untuk mengumpulkan, menganalisis, dan "mencampur" metode kuantitatif dan kualitatif dalam suatu penelitian untuk memahami permasalahan penelitian (Creswell \& Plano Clark, 2011). Asumsi dasarnya adalah penggunaan metode kuantitatif dan kualitatif, secara gabungan, memberikan pemahaman yang lebih baik tentang permasalahan dan pertanyaan penelitian daripada sendiri-sendiri.

Pertimbangan dengan menggunakan metode ini berdasarkan asumsi peneliti bahwa penelitian dapat menggunakan mix methods karena masing-masing metode punya kekuatan dan kelemahan. Metode mixed methods ini akan saling melengkapi data penelitian yang dikumpulkan oleh peneliti (Hanson, WE. Et.al. 2010; Sugiyono 2013). Dari berbagai strategi dalam pendekatan campuran yang telah dijelaskan oleh Craswell $(2015,1102)$ maka dalam penelitian ini menggunakan desain kovergen (convergent design). Pada bagian pengolahan data menggabungkan data kuantitatif dan kualitatif secara kongruen, menggabungkan datanya, membandingkan hasil-hasilnya, dan menjelaskan semua dideskripsikan dalam hasilnya. Dalam rancangan ini peneliti mengumpulkan data kuantitatif dan kualitatif secara kongruen selama penelitian, kemudian membandingkan hasil dari analisis kuantitatif dan kualitatif jika kedua basis data mendapatkan hasil yang serupa. Setelah itu mendeskripsikan hasil kuantitatif dan kualitatif berdampingan.

Penelitian ini menggunakan dua jenis instrumen, yaitu instrumen tes dan non tes. Instrumen tes yang digunankan berupa tes kemampuan penalaran dan tes kemampuan komunikasi matematis yang disusun berdasarkan indikiator masing-masing kemampuan, sedangkan instrumen non tes berupa angket self-efficacy yang terdiri dari 32 pernyataan, pedoman wawancara, serta lembar observasi guru dan lembar observasi peserta didik. 


\section{HASIL PENELITIAN DAN PEMBAHASAN}

Proses pembelajaran pada penelitian ini dilaksanakan sebanyak sembilan kali pertemuan, pada pertemuan ketiga, pertemuaan keenam dan pertemuan kesembilan diadakan tes untuk mengukur kemampuan kognitif peserta didik sesuai dengan indikator kemampuan penalaran dan komunikasi matematis. Pada setiap pertemuan, langkahlangkah model cooperative learning tipe team assisted individualization (TAI) dideskripsikan sesuai dengan tahapan yang terdiri dari : 1) placement test, pada tahap ini untuk mengatahui kemampuan awal peserta didik menggunakan nilai dari pertemuan sebelumnya; 2) teams, pada tahap ini pengelompokkan dilaksanakan secara heterogen disesuaikan dengan tingkat kemampuan kognitif, 4 kelompok terdiri dari 4 orang, 2 kelompok terdiri dari 5 orang; 3) student creative, guru menekankan dan menciptakan persepsi bahwa keberhasilan setiap peserta didik ditentukan oleh kelompoknya; 4) teams ttudy, peserta didik diberikan lembar aktivitas peserta didik (LAPD) diselesaikan secara berkelompok. Guru memberikan waktu pengerjaan selama 30 menit. Setiap kelompok berdiskusi, pada menit ke 5 peserta didik mulai menanyakan tentang materi terkait dengan transpose yang terdapat dalam LAPD, guru langsung memberikan bantuan secara individual, kemudian mengecek kelompok satu persatu untuk melihat pekerjaan peserta didik agar tidak terjadi salah konsep. Selain itu, guru juga mengarahkan kepada peserta didik untuk saling berbagi pengetahuan kepada temen sekelompoknya maupun kelompok yang lain jika memang masih memerlukan bantuan; untuk peserta didik yang masih belum mengerti, guru segera melakukan pendekatan individu lalu memberika penjelasan kemudian memberikan pengarahan, sehingga hasil yang didapatkan akan maksimal, 5) fact test, guru memberikan quis sebagai alternative pemahaman terhadap materi; 6) team score dan team recognition, guru memberikan skor pada hasil kerja kelompok, dan mengumumkan perolehan skor tertinggi yang diperoleh oleh kelompok dan reward yang diberikan berupa point tambahan 5 bintang kepada anggota kelompok. Kemudian guru memaparkan kembali tentang pengertian matriks dan jenis-jenisnya; 7) whole-class units, guru merefleksi kegiatan pembelajaran yang sudah berlangsung dan menyampaikan materi

yang akan dipelajari pada pertemuan berikutnya mengenai operasi matriks yaitu pengurangan dan penjumlahan matriks. Guru memberikan pekerjaan rumah sebagai bahan untuk latihan. Guru menutup pertemuan dengan memberikan salam akhir kepada peserta didik. 


\section{Hasil Tes Kemampuan Penalaran dan Komunikasi Matematis}

Tabel 1 Rata-Rata Ketercapaian Indikator Kemampuan Penalaran dan Komunikasi

\begin{tabular}{cccccccccc}
\hline \multirow{2}{*}{ No } & \multirow{2}{*}{ Tes } & \multicolumn{4}{c}{ Kemampuan Penalaran } & \multicolumn{3}{c}{ Kemampuan Komunikasi } \\
\cline { 3 - 9 } & & 1 & 2 & 3 & 4 & 1 & 2 & 3 & 4 \\
\hline 1 & Tes 1 & 100 & 88 & 81 & 73 & 74,68 & 66,35 & 69,23 & 83,65 \\
2 & Tes 2 & 100 & 96,15 & 84,61 & 96,15 & 92,31 & 80,77 & 92,31 & 76,93 \\
3 & Tes 3 & 100 & 96,15 & 92,31 & 92,3 & 92,31 & 80,77 & 96,15 & 96,15 \\
\hline
\end{tabular}

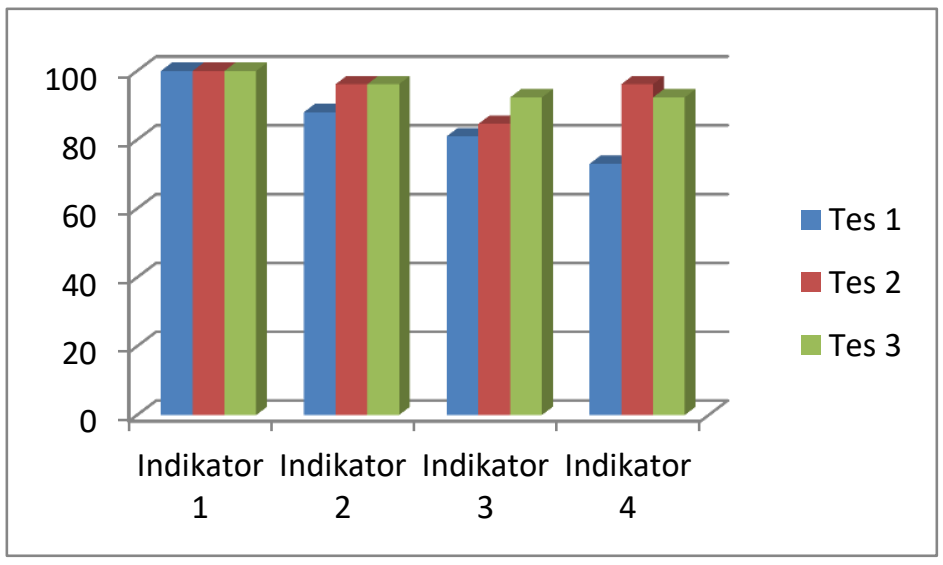

Gambar 1. Ketercapaian Indikator Kemampuan Penalaran Matematis

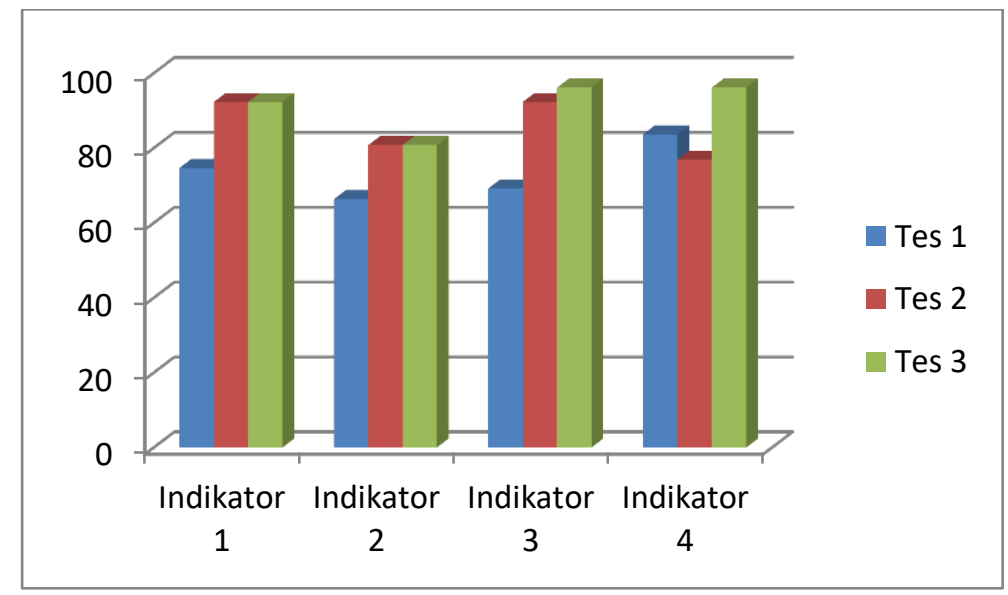

Gambar 2. Ketercapaian Indikator Kemampuan Komunikasi Matematis

Tabel 2. Rata-rata Nilai Tes dan Ketercapaian Kemampuan Penalaran dan Komunikasi Matematis

\begin{tabular}{cccccc}
\hline \multirow{2}{*}{ No } & \multirow{2}{*}{ Tes } & \multicolumn{2}{c}{ Kemampuan Penalaran } & \multicolumn{2}{c}{ Kemampuan Komunikasi } \\
\cline { 3 - 6 } & & Nilai Tes & $\begin{array}{c}\text { Ketuntasan } \\
(\%)\end{array}$ & $\begin{array}{c}\text { Rata-Rata } \\
\text { Nilai Tes }\end{array}$ & Ketuntasan (\%) \\
\hline 1 & Tes 1 & 73 & 77 & 77 & 85 \\
2 & Tes 2 & 78,63 & 76,92 & 76,83 & 80,77 \\
3 & Tes 3 & 83,81 & 92,31 & 78,80 & 96,15 \\
\hline
\end{tabular}




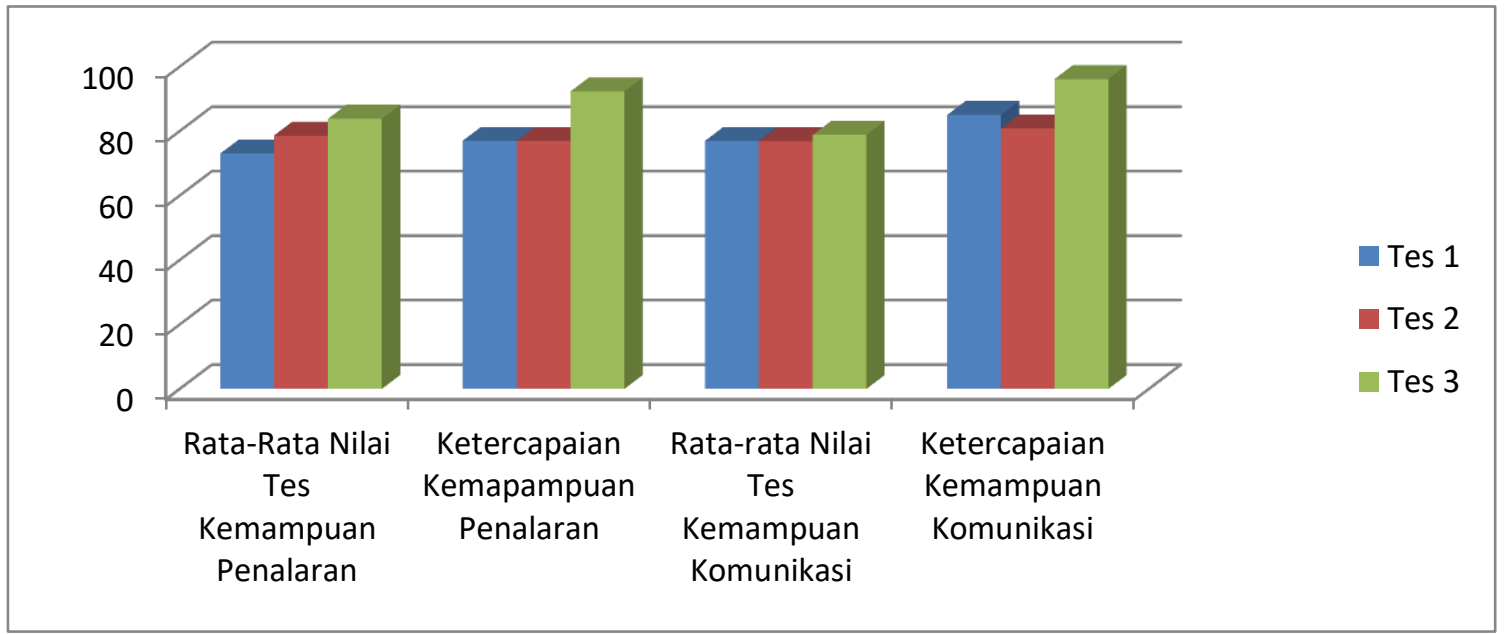

Gambar 3. Rata-Rata Nilai Tes dan Ketercapaian Kemampuan Penalaran dan Komunikasi Matematis

Berdasarkan hasil observasi pada peserta didik dan guru, dapat ditarik kesimpulan terdapat peningkatan aktivitas peserta didik dan aktivitas guru selama selama proses pembelaran matematika dengan model cooperative learning tipe team assisted individualization (TAI), seperti terlihat pada gambar tabel berikut :

Tabel 3. Rata-rata Aktivitas Peserta Didik dan Guru

\begin{tabular}{cccc}
\hline No & Tes & $\begin{array}{c}\text { Aktivitas Peserta } \\
\text { Didik }(\%)\end{array}$ & $\begin{array}{c}\text { Aktivitas } \\
\text { Guru (\%) }\end{array}$ \\
\hline 1 & Tes 1 & 58 & 79 \\
2 & Tes 2 & 68 & 84 \\
3 & Tes 3 & 72 & 94 \\
\hline
\end{tabular}

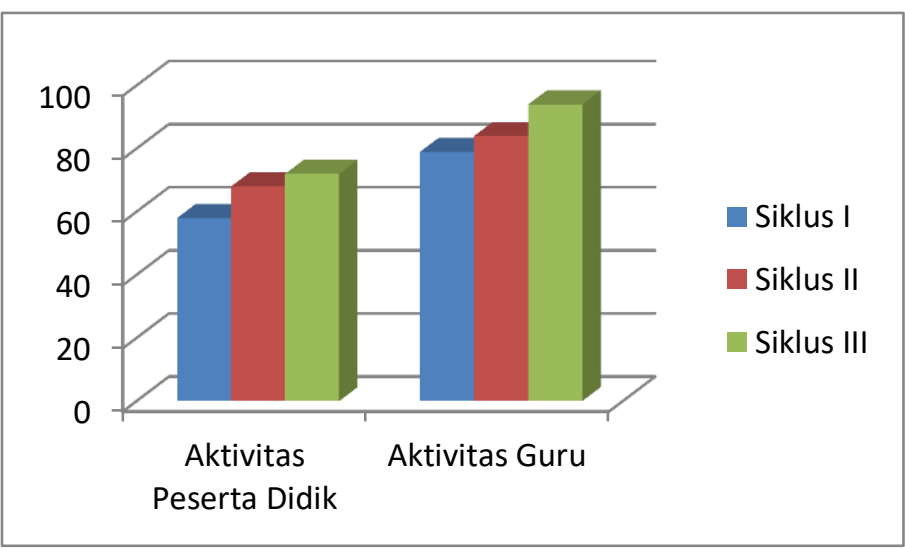

Gambar 4. Rekapitulasi Persentase Hasil Observasi Peserta Didik dan Guru

Sesuai dengan rencana pelaksanaan pembelajaran yang tercantum dalam RPP dan berdasarkan pada tercapainya indikator kinerja, maka penelitian ini dikatakan terdapat peningkatan. Dengan demikian hipotesis penelitian ini telah tercapai bahwa penguasaan 
konsep matematika melalui kemampuan penalaran dan komunikasi matematis hasilnya meningkat menggunakan model cooperative learning tipe team assistes individualization (TAI).

\section{Hasil Wawancara}

Dari hasil wawancara dari penelitian ini terkumpul dari 3 peserta didik, yang terdiri dari 1 peserta didik berkemampuan tinggi, 1 peserta didik berkemampuan rendah, dan 1 peserta didik berkemampuan rendah. Data hasil wawancara diringkas berdasarkan pedoman wawancara yang terdapat pada tabel di bawah ini :

\section{Tabel 5. Hasil Wawancara}

\begin{tabular}{|c|c|c|}
\hline No & Pertanyaan yang Diajukan & Respon Peserta Didik \\
\hline 1 & $\begin{array}{l}\text { Bagaimanacara anda memahami } \\
\text { masalah yang diberikan? }\end{array}$ & $\begin{array}{l}\text { - Mencoba menyelesaikannya dengan mengaitkan } \\
\text { permaslahan yang saudah pernah dipelajari sebelum } \\
\text { dilaksanakan tes. } \\
\text { - } \text { Menyelesaikan sesuai kemampuan } \\
\text { - Menyelesaikan sesuai apa yang saya bisa }\end{array}$ \\
\hline 2 & $\begin{array}{l}\text { Cara apa yang anda gunakan } \\
\text { untuk menentukan jawaban } \\
\text { yang diberikan? }\end{array}$ & $\begin{array}{l}\text { - Menentukan titik permasalahan apa yang diketahui } \\
\text { dan apa yang ditanyakan dan saya mengerjakan dari } \\
\text { soal yang mudah menurut saya. Karena dengan } \\
\text { seperti itu akan memudahkan saya menyelsaikan } \\
\text { semuanya. }\end{array}$ \\
\hline & & $\begin{array}{l}\text { - Menentukan yang diketahui dan menjawab yang } \\
\text { ditanyakan setelah itu saya kerjakan yang mudah } \\
\text { dulu } \\
\text { - Mencari tahu yang diketahui lalu menjawabnya. }\end{array}$ \\
\hline 3 & $\begin{array}{l}\text { Apakah jawaban anda sudah } \\
\text { benar? } \\
\text { Mengapa? }\end{array}$ & $\begin{array}{l}\text { - Saya yakin benar, karena saya sudah belajar sebelum } \\
\text { dilaksanakan tes, dan saya sudah paham cara } \\
\text { menyelesaikan soal tes tersebut } \\
\text { - Tidak yakin, karena masih ada yang belum dipahami } \\
\text { - Tidak yakin, masih bingung dan belum mengerti }\end{array}$ \\
\hline 4 & $\begin{array}{l}\text { Apakah anda memeriksa } \\
\text { kembali jawaban anda? } \\
\text { Mengapa? }\end{array}$ & $\begin{array}{l}\text { - Ya, untuk memastikan khawatirnya ada } \\
\text { penghitungan atau rumus saya yang salah } \\
\text { - Ya, mengecek jawaban } \\
\text { - Ya, takut ada yang salah }\end{array}$ \\
\hline 5 & $\begin{array}{l}\text { Bagaimana pendapatmu tentang } \\
\text { pembelajaran yang dilakukan } \\
\text { guru matematika selama ini? } \\
\text { Mengapa }\end{array}$ & $\begin{array}{l}\text { - Menurut saya menyenangkan, karena saya bisa } \\
\text { berbagi dengan teman sekelompok saya, meskipun } \\
\text { saya suka kesal kalau temen saya tidak mengerti } \\
\text { terus dengan apa yang saya jelaskan, dan guru selalu } \\
\text { membantu saya untuk menjelaskan kembali. Tapi } \\
\text { saya selalu berusaha mencari tahu sendiri sebelum } \\
\text { saya bertanya kepada guru } \\
\text { - Saya suka, karena saya merasa terbantu dengan } \\
\text { adanya pembelajaran kelompok } \\
\text { Menyenangkan, saya jadi lebih berani untuk } \\
\text { bertanya kepada guru, karena bisa langsung } \\
\text { didiskusikan di tempat }\end{array}$ \\
\hline 6 & $\begin{array}{l}\text { Apakah menurut anda, cara } \\
\text { belajar yang kita lakukan } \\
\text { bersama dapat meningkatkan } \\
\text { kemampuan penalaran \& }\end{array}$ & $\begin{array}{l}\text { - Ya, karena kita terus mencari penyelesaian } \\
\text { permasalahan sampai benar-benar paham, meskipun } \\
\text { soalnya sedikit membingungkan, tapi lama kelamaan } \\
\text { saya bisa menyelesaikannya. }\end{array}$ \\
\hline
\end{tabular}




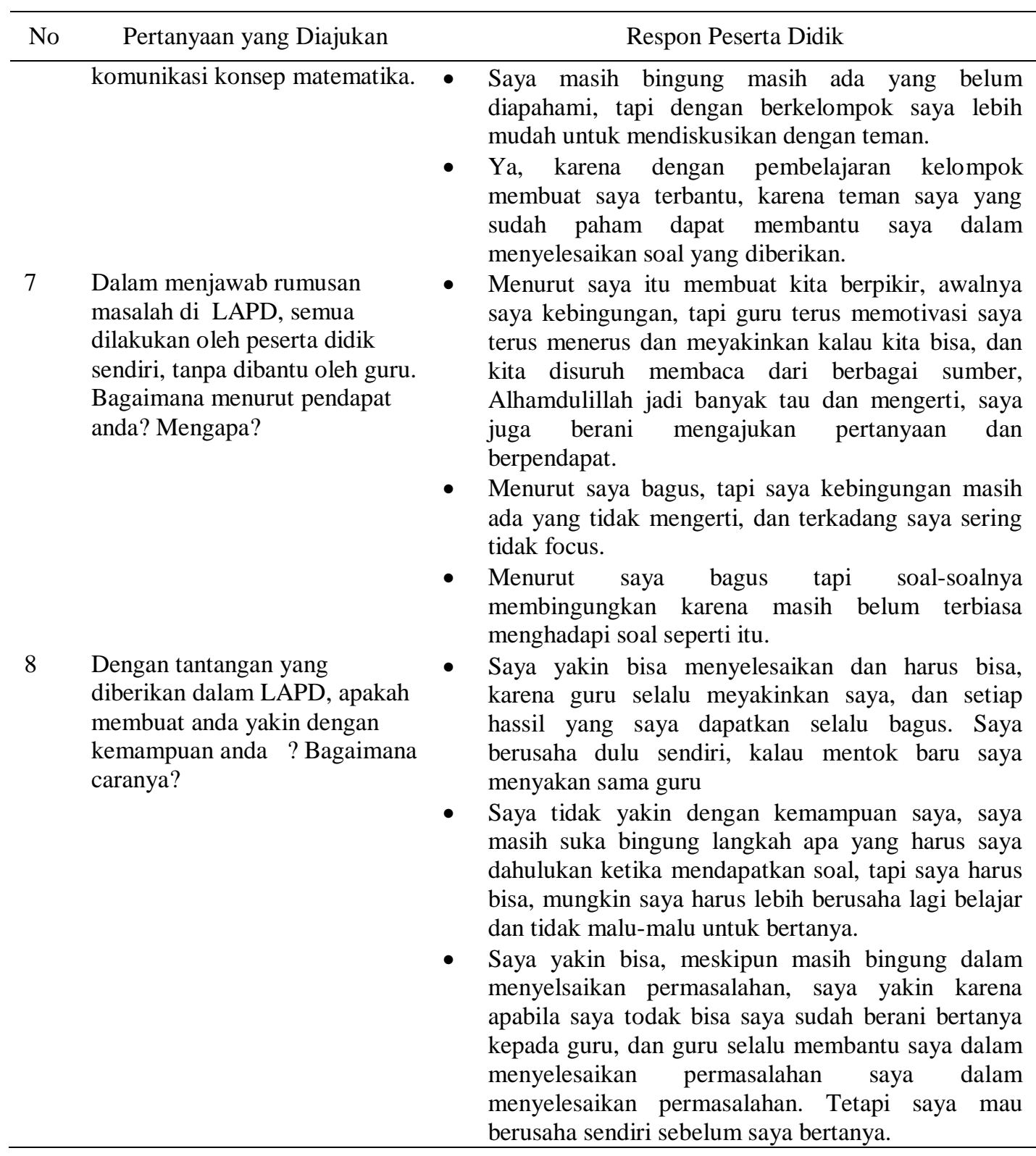

\section{Hasil Analisis Self Efficacy}

Penilaian pada angket self efficacy disesuaikan dengan dimensi self efficacy, yaitu :

(1) dimensi magnitude, berhubungan dengan tingkat kesulitan yang diyakini oleh individu untuk dapat diselesaikan; (2) dimensi strength, berhubungan dengan tingkat kekuatan atau kelemahan keyakinan individu tentang kompetensi yang dipersepsinya; (3) dimensi generality, berhubungan dengan luas bidang atau tingkat pencapaian keberhasilan seseorang dalam mengatasi atau menyelesaikan masalah atau tugas-tuganya.

Berdasarkan hasil yang tertera dalam gambar diketahui peserta didik memiliki self efficacy yang sedang terhadap pembelajaran matematika dengan model cooperative learning tipe Team Assisted Individualization (TAI). 


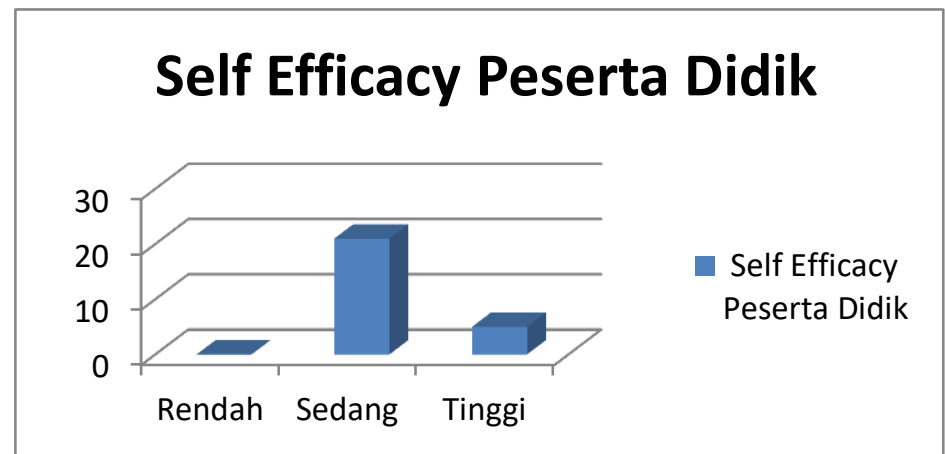

Gambar 5. Kategori Self Efficacy Peserta Didik

Berdasarkan hasil tabel 43 diketahui peserta didik pada dimensi magnitude memiliki self efficacy yang sedang terhadap pembelajaran matematika dengan model cooperative learning tipe Team Assisted Individualization (TAI).

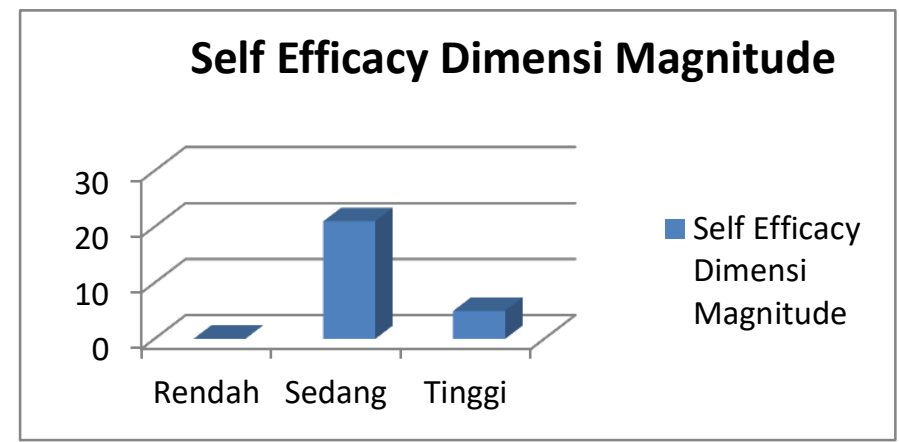

Gambar 6. Kategori Self Efficacy Dimensi Mangnitude Peserta Didik

Berdasarkan hasil tabel 4.12 dan gambar 4.8 diketahui peserta didik pada dimensi strength memiliki se;f efficacy yang sedang terhadap pembelajaran matematika dengan model cooperative learning tipe Team Assisted Individualization (TAI)

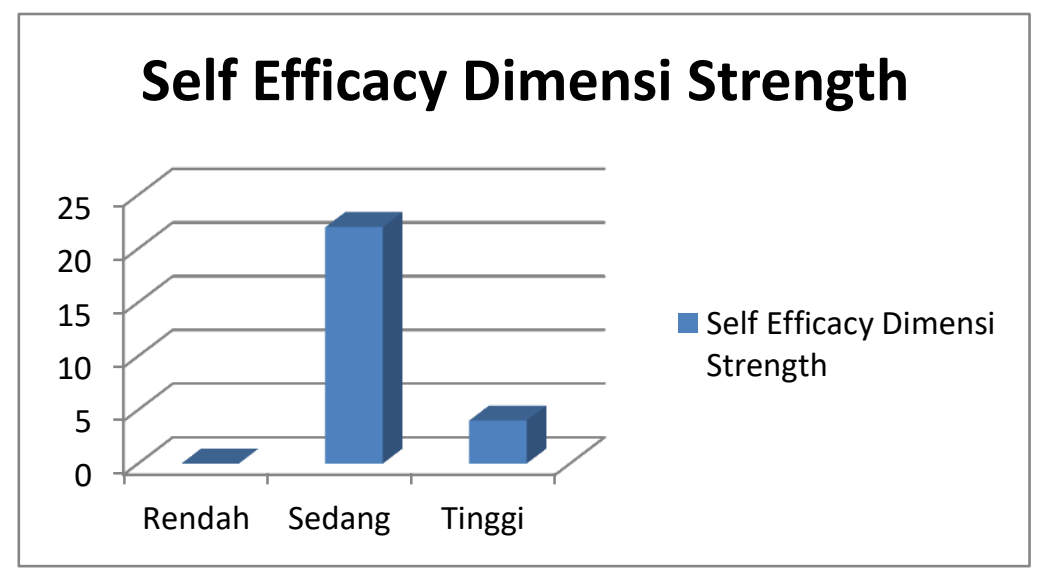

Gambar 7. Kategori Self Efficacy Dimensi Strength Peserta Didik 
Berdasarkan hasil tabel 4.13 dan gambar 4.9 perhitungan diatas diketahui peserta didik pada dimensi generality memiliki se;f efficacy yang sedang terhadap pembelajaran matematika dengan model cooperative learning tipe TAI.

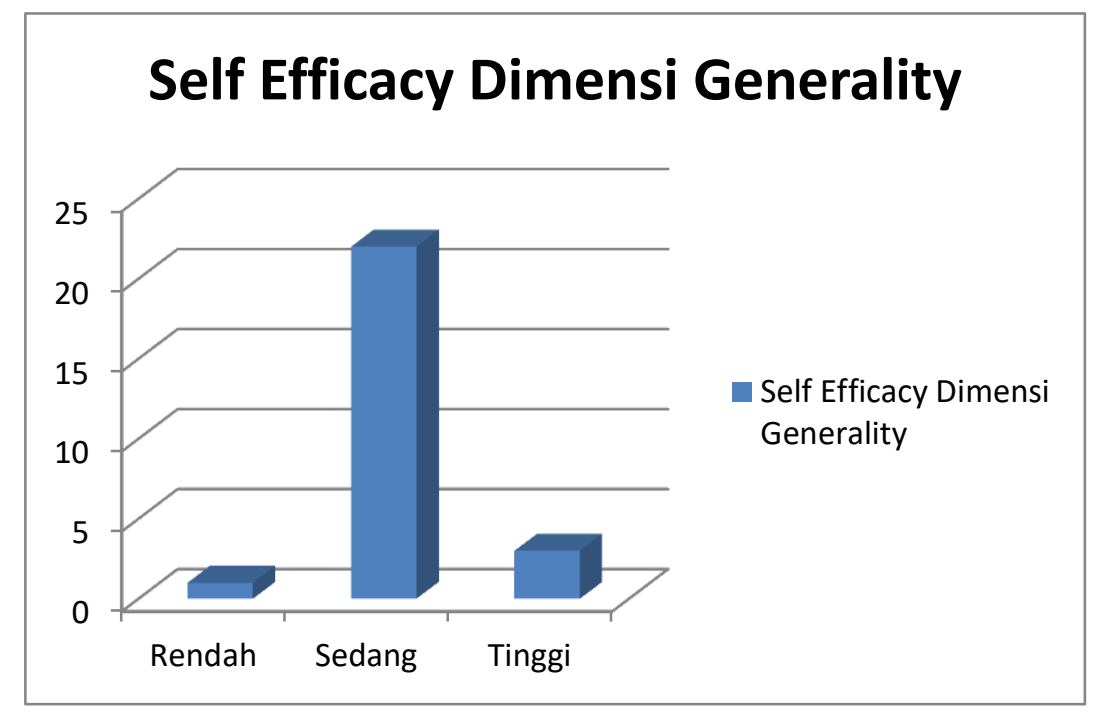

Gambar 8. Kategori Self Efficacy Dimensi Generality Peserta Didik

\section{Hasil Uji Regresi Sederhana Kemampuan Penalaran Matematis}

Tabel 6. Uji Regresi Sederhana Kemampuan Penalaran

\begin{tabular}{rlrrrrr}
\multicolumn{7}{c}{ ANOVA $^{\mathbf{a}}$} \\
Model & & Sum of Squares & df & Mean Square & F & Sig. \\
\hline \multirow{3}{*}{1} & Regression & 3454,108 & 1 & 3454,108 & 94,495 &, $000^{\mathrm{b}}$ \\
& Residual & 877,276 & 24 & 36,553 & & \\
& Total & 4331,385 & 25 & & &
\end{tabular}

a. Dependent Variable: Postes_Penalaran

b. Predictors: (Constant), Pretes_Penalaran

\section{Coefficients $^{\mathrm{a}}$}

\begin{tabular}{rlrrrrr}
\hline Model & & \multicolumn{2}{c}{$\begin{array}{c}\text { Unstandardized } \\
\text { Coefficients }\end{array}$} & $\begin{array}{c}\text { Standardized } \\
\text { Coefficients }\end{array}$ & t & \multirow{2}{*}{ Sig. } \\
\cline { 3 - 6 } & & \multicolumn{1}{c}{ B } & Std. Error & Beta & & \\
\hline \multirow{2}{*}{1} & (Constant) & 55,106 & 2,531 & & 21,769 &, 000 \\
& Pretes_Penalaran &, 716 &, 074 &, 893 & 9,721 &, 000 \\
\hline
\end{tabular}

a. Dependent Variable: Postes_Penalaran

Berdasarkan tabel 47 terlihat bahwa $F=94,495$ dengan signifikansi $0,000<0,05$, maka model regresi dapat dipakai untuk memprediksi variabel partisipasi. nilai t hitung = 9,721 dengan nilai signifikansi $0,000<0,05$, maka $\mathrm{H}_{0}$ ditolak, maka penerapan model cooperative learning tipe Time Assisted Individualization (TAI) dapat meningkatkan kemampuan penalaran pada peserta didik. 


\section{Hasil Uji regresi Sederhana Kemampuan Komunikasi Matematis}

Tabel 7. Uji Regresi Sederhana Kemampuan Komunikasi

\begin{tabular}{rlrrrrr}
\multicolumn{7}{c}{ ANOVA $^{\mathbf{a}}$} \\
\hline Model & & Sum of Squares & Df & Mean Square & F & \multicolumn{1}{c}{ Sig. } \\
\hline \multirow{4}{*}{1} & Regression & 2094,615 & 1 & 2094,615 & 21,082 &, $000^{\circ}$ \\
& Residual & 2384,501 & 24 & 99,354 & & \\
& Total & 4479,115 & 25 & & & \\
\hline
\end{tabular}

a. Dependent Variable: Postes_Komunikasi

b. Predictors: (Constant), Pretes_Komunikasi

Coefficients $^{a}$

\begin{tabular}{|c|c|c|c|c|c|c|}
\hline \multirow{2}{*}{\multicolumn{2}{|c|}{ Model }} & \multicolumn{2}{|c|}{$\begin{array}{l}\text { Unstandardized } \\
\text { Coefficients }\end{array}$} & \multirow{2}{*}{$\begin{array}{c}\text { Standardized } \\
\text { Coefficients } \\
\text { Beta }\end{array}$} & \multirow[t]{2}{*}{$\mathrm{t}$} & \multirow[t]{2}{*}{ Sig. } \\
\hline & & $\mathrm{B}$ & Std. Error & & & \\
\hline \multirow{2}{*}{1} & (Constant) & 57,581 & 4,320 & & 13,329 & ,000 \\
\hline & Pretes Komunikasi &, 563 & ,123 & ,684 & 4,592 &, 000 \\
\hline
\end{tabular}

a. Dependent Variable: Postes_Komunikasi

Berdasarkan tabel 48 terlihat bahwa $\mathrm{F}=21,082$ dengan signifikansi $\quad 0,000<0,05$, maka model regresi dapat dipakai untuk memprediksi variabel partisipasi. Nilai $t$ hitung $=$ 4,592 dengan nilai signifikansi $0,000<0,05$, maka $\mathrm{H}_{0}$ ditolak, maka penerapan model cooperative learning tipe Time Assisted Individualization (TAI) dapat meningkatkan kemampuan komunikasi pada peserta didik.

Hubungan Antara Kemampuan Penalaran dan Komunikasi Metematis terhadap Self

\section{Efficacy}

Tabel 8. Uji Hubungan antara Kemampuan Penalaran, Komunikasi, serta Self Eficacy Berdasarkan pada Dimensi

\begin{tabular}{|c|c|c|c|c|c|c|}
\hline \multicolumn{7}{|c|}{ Correlations } \\
\hline \multirow{4}{*}{ MAGNITUDE } & & MAGNITUDE & STRENGTH & GENERALITY & PENALARAN & KOMUNIKASI \\
\hline & Pearson Correlation & 1 & ,939 & ,923 & ,681 & ,551" \\
\hline & Sig. (2-tailed) & & ,000 & ,000 &, 000 & ,004 \\
\hline & $\mathrm{N}$ & 26 & 26 & 26 & 26 & 26 \\
\hline \multirow[t]{3}{*}{ STRENGTH } & Pearson Correlation & ,939 & 1 & ,867 & ,681 & ,462 \\
\hline & Sig. (2-tailed) & ,000 & & ,000 & ,000 & 017 \\
\hline & $\mathrm{N}$ & 26 & 26 & 26 & 26 & 26 \\
\hline \multirow[t]{3}{*}{ GENERALITY } & Pearson Correlation & 923 & 867 & 1 & 672 &, 550 \\
\hline & Sig. (2-tailed) &, 000 &, 000 & &, 000 &, 004 \\
\hline & $\mathrm{N}$ & 26 & 26 & 26 & 26 & 26 \\
\hline \multirow[t]{3}{*}{ PENALARAN } & Pearson Correlation & ,681 & ,681 & ,672 & 1 & ,745 \\
\hline & Sig. (2-tailed) & ,000 &, 000 & ,000 & &, 000 \\
\hline & $\mathrm{N}$ & 26 & 26 & 26 & 26 & 26 \\
\hline \multirow[t]{3}{*}{ KOMUNIKASI } & Pearson Correlation & $551 \ldots$ & 462 &, 550 &, $745^{\prime \prime}$ & 1 \\
\hline & Sig. (2-tailed) & ,004 & 017 & ,004 & ,000 & \\
\hline & $\mathrm{N}$ & 26 & 26 & 26 & 26 & 26 \\
\hline
\end{tabular}

${ }^{*}$. Correlation is significant at the 0.05 level (2-tailed).

Berdasarkan Tabel 50, nilai signifikansi korelasi kemampuan penalaran dengan kemampuan komunikasi adalah 0,000 dan koefisien korelasinya adalah 0,745. Karena $0,000<0,05$ maka $\mathrm{H}_{1}$ diterima, artinya terdapat hubungan positif antara kemampuan 
penalaran dengan kemampuan komunikasi matematis peserta didik dan berdasarkan klasifikasi interpretasi koefisien korelasi menurut J.P Guillford (Ruseffendi, 2005:160) tingkat korelasi dari keduanya adalah tinggi.

Nilai signifikansi korelasi kemampuan penalaran dengan self efficacy pada dimensi magnitude adalah 0,000 dan koefisien korelasinya adalah 0,681. Karena 0,000 <0,05 maka $\mathrm{H}_{1}$ diterima, artinya terdapat hubungan positif antara kemampuan penalaran dengan self efficacy pada dimensi magnitude peserta didik dan berdasarkan klasifikasi interpretasi koefisien korelasi menurut J.P Guillford (Ruseffendi, 2005:160) tingkat korelasi dari keduanya adalah sedang.

Nilai signifikansi korelasi kemampuan penalaran dengan self efficacy pada dimensi strength adalah 0,000 dan koefisien korelasinya adalah 0,681. Karena 0,000 0,05 maka $\mathrm{H}_{1}$ diterima, artinya terdapat hubungan positif antara kemampuan penalaran dengan self efficacy pada dimensi strength peserta didik dan berdasarkan klasifikasi interpretasi koefisien korelasi menurut J.P Guillford (Ruseffendi, 2005:160) tingkat korelasi dari keduanya adalah sedang.

Nilai signifikansi korelasi kemampuan penalaran dengan self efficacy pada dimensi generality adalah 0,000 dan koefisien korelasinya adalah 0,672. Karena 0,000<0,05 maka $\mathrm{H}_{1}$ diterima, artinya terdapat hubungan positif antara kemampuan penalaran dengan self efficacy pada dimensi generality peserta didik dan berdasarkan klasifikasi interpretasi koefisien korelasi menurut J.P Guillford (Ruseffendi, 2005:160) tingkat korelasi dari keduanya adalah sedang.

Nilai signifikansi korelasi kemampuan komunikasi dengan self efficacy pada dimensi magnitude adalah 0,004 dan koefisien korelasinya adalah 0,551. Karena 0,004< 0,05 maka $\mathrm{H}_{1}$ diterima, artinya terdapat hubungan positif antara kemampuan komunikasi dengan self efficacy dimensi magnitude peserta didik dan berdasarkan klasifikasi interpretasi koefisien korelasi menurut J.P Guillford (Ruseffendi, 2005:160) tingkat korelasi dari keduanya adalah sedang.

Nilai signifikansi korelasi kemampuan komunikasi dengan self efficacy dimensi strength adalah 0,017 dan koefisien korelasinya adalah 0,462. Karena 0,017 < 0,05 maka $\mathrm{H}_{1}$ diterima, artinya terdapat hubungan positif antara kemampuan komunikasi dengan self efficacy dimensi strength peserta didik dan berdasarkan klasifikasi interpretasi koefisien korelasi menurut J.P Guillford (Ruseffendi, 2005:160) tingkat korelasi dari keduanya adalah sedang. 
Nilai signifikansi korelasi kemampuan komunikasi dengan self efficacy pada dimensi generality adalah 0,004 dan koefisien korelasinya adalah 0,550. Karena 0,004 < 0,05 maka $\mathrm{H}_{1}$ diterima, artinya terdapat hubungan positif antara kemampuan komunikasi dengan self efficacy dimensi generality peserta didik dan berdasarkan klasifikasi interpretasi koefisien korelasi menurut J.P Guillford (Ruseffendi, 2005:160) tingkat korelasi dari keduanya adalah sedang.

\section{KESIMPULAN}

Berdasarkan hasil penelitian, pengolahan data dan analisis data, serta pengujian hipotesis yang telah dilakukan, dapat disimpulkan bahwa :

1. penerapan model cooperative learning tipe Time Assisted Individualization (TAI) dapat meningkatkan kemampuan penalaran peserta didik.

2. penerapan model cooperative learning tipe Time Assisted Individualization (TAI) dapat meningkatkan kemampuan komunikasi peserta didik.

3. kemampuan penalaran dan komunikasi matematis selama pembelajaran berlangsung dapat diatasi dengan baik, dan diperbaiki pada setiap siklusnya.

4. perkembangan self-eficacy peserta didik selama proses pembelajaran matematika dengan penerapan pembelajaran kooperatif tipe kooperatif tipe Time Assisted Individualization (TAI) berada pada kategori sedang baik secara keseluruhan maupun berdasarkan dimensi magnitude, strength, dan generality.

5. terdapat hubungan yang positif antara kemampuan penalaran dan kemampuan komunikasi matematis dengan self efficacy peserta didik.

6. kendala yang dihadapi peserta didik dalam menyelesaikan tes kemampuan penalaran dan komunikasi matematis bisa diatasi dalam batas pencapaian kriteria ketuntasan minimal yang sudah ditetapkan pada awal penelitian dan didakan evaluasi dalam setiap pertemuannya.

\section{REFERENSI}

Arikunto, Suharsimi. (2002). Dasar - dasar Evaluasi Pendidikan. Jakarta : Bumi Aksara.

Arikunto, Suharsimi. (2006). Prosedur Penelitian Suatu Pendekatan Praktik. Jakarta : PT. Rineka Cipta.

Arikunto, Suharsimi. (2007). Penelitian Tindakan Kelas. Jakarta: PT. Rineka Cipta. 
Bandura, A. (1997). Self-efficacy in Charging Societies. New York: Cambridge University Press

Balai Pustaka. (2004). Kamus Besar Bahasa Indonesia. Jakarta. Dinas Pendidikan dan Kebudayaan.

Depdiknas, (2008). Permendikbud No. 22 Tahun 2006 tentang Standar Isi untuk Satuan Pendidikan Dasar dan Menengah, Jakarta: Direktorat Manajemen Pendidikan Dasar dan Menengah

Dzulfikar, (2014). Kemampuan Pemecahan Masalah Metematis, Self-efficacy dan Anxiety Siswa SMP dalam Cooperative Learning Tipe Group Investigation. Tesis Sps UPI, Bandung. (Tidak diterbitkan)

Frosch, A.C \& Simms, V. Understanding the role of reasoning in mathematical achievement. http://ceur-ws.org/Vol-1419/paper0105.pdf . [12 Agustus 2017]

Hamalik, (2014). Kurikulum dan Pembelajaran. Jakarta: Bumi Aksara.

Hendriana \& Soemarmo, (2014). Penilaian Pembelajaran Matematika. Bandung: PT. Refika aditama.

Hendriana \& Soemarmo, (2017). Hard Skills dan Soft Skills Matematik Siswa. Bandung: PT. Refika aditama.

Hastuti, (2012). Self-Eficacy Mahasiswa Terhadap Matematika. Makalah FMIPA UNY. [online]. Tetsedia:http://math.uny. [12 september 2016]

Herliani dan Indrawati, (2009). http://dinasti-tamblang.blogspot.com/2013/05/self -efficacy-matematika-siswa.html. [5 September 2016]

Hoban, S \& Hoban, G. (2014). Self Esteem, Self Efficacy, and Self Ditected Learning: Attemping to Undo the Confusion. International Journal of Self Directed Learning, Volume 1, Number 2.

Indrawan \& Yaniawati, (2014). Metodologi Penelitian Kuantitatif, Kualitatif, dan Campuran untuk Manajemen, Pembangunan, dan Pendidikan. Bandung: Refika Aditama.

Lesmana Hendra, Ratu Ilma IP , Somakim. Komunikasi Matematis. http://portalgaruda.org/download_article.php?article=97550\&val=612. [27 Agustus 2016]

Lestari \& Yudhanegara, (2015). Penelitian Pendidikan Matematika. Bandung: PT. Refika Aditama

Luitel, B.C, (2001). Multiple Representations of Mathematical Learning. (online),(http://www.matedu.cinvestav.mx/adalira.pdf), diakses 5 September 2016 
Handayani (2016). Peningkatan Kemampuan Penalan dan Komunikasi Matematis serta Self-efficacy Siswa SMP melalui Model Situation Learning. Tesis SPs UPI, Bandung. (Tidak diterbitkan)

Pakpahan, H. (2014). Analisis Self-Efficacy dan Kesalahan dalam Mengerjakan Soal Penalaran Matematika Siswa SMA. Tesis SPs UPI. (Tidak diterbitkan).

Purdavood, G.R. \& Wachira,P. (2015). Impotent of MathematicalCommunication and Discource in Secondary Classrooms. (Online) (http://www.iosjournals.org/ios-jm/papers/Vol13-issue1/Version5/I1301056066.pdf), diakses 12 Agustus 2017

Ruseffendi, E. T. (1991). Dasar - dasar penelitian pendidikan \& Hendriana \& Soemarmo, (2014). Penilaian Pembelajaran Matematika. Bandung:

PT. Refika aditama.

Bidang Non-

Eksakta Lainnya. Bandung: Tarsito.

Sanjaya, Wina, (2006). Strategi Pembelajaran Berorientasi Standar Proses Pendidikan. Jakarta: Kencana Prenada Media.

Shadiq Fadjar, (2008). Psikologi Pembelajaran Matematika di SMA. Yogyakarta: Pusat Pengembangan dan Pemberdayaan Pendidik dan Tenaga Kependidikan Matematika.

Setiawan, (2008). Strategi Pembelajaran Matematika SMA. Yogyakarta: Pusat Pengembangan dan Pemberdayaan Pendidik dan Tenaga Kependidikan Matematika.

Suherman, E. (2003). Evaluasi Pembelajaran Matematika. Bandung: Universitas Pendidikan Indonesia. FPMIPA UPI Bandung.

Suherman, E. (2003). Strategi Pembelajaran Matematika Kontemporer. Malang: IMSTEP JICA.

Sumarmo, U. (2015). Pengembangan dan Contoh Butir Skala Nilai, karakter, Budaya dan Aspek Afektif Lain dalam Pembelajaran Matematika. [online]. Tersedia:http//www.utari-sumarmo@dosen.stkipsiliwangi.pdf. [18 Juli 2016]

Suyadi, (2012). Buku panduan guru professional Penelitian Tindakan Kelas (PTK) dan Penelitian Tindakan Sekolah (PTS). Yogyakarta: Andi.

Sugiyono, (2010). Statistika untuk Penelitian. Bandung: Alfabeta.

Sugiyono, (2016). Metode Penelitian Kombinasi ( Mixed Methods ). Bandung: Alfabeta 
Tasdikin. (2012). Pembelajaran Berbasis Masalah untuk meningkatkan Kemampuan komunikasi dan Pemecahan Masalah Matematis Siswa SMP. Tesis SPs UPI. (Tidak diterbitkan)

Tika, (2016). Meningkatkan Kemampuan Komunikasi dan Koneksi Matematis serta Self-efficacy Siswa SMP. Tesis SPs. UPI. (Tidak diterbitkan).

Ulpah Maria, (2013). Peningkatan Kemampuan Penalaran Satististis dan Self-Eficacy Siswa Madrasah Aliyah Melalui Pembelajaran Kontekstual. Desertasi FPMIPA UPI. (Tidak Diterbitkan)

Wahyudin,(2012). Filsafat dan Model-Model Pembelajaran Matematika ( Pelengkap untuk Meningkatkan Kompetensi Pedagogis Para Guru dan Calon Guru Profesional). Bandung: Mandiri.

Wahyudin, (2012). Kapita Selekta Matematika. Bandung: Rizqi Press. 